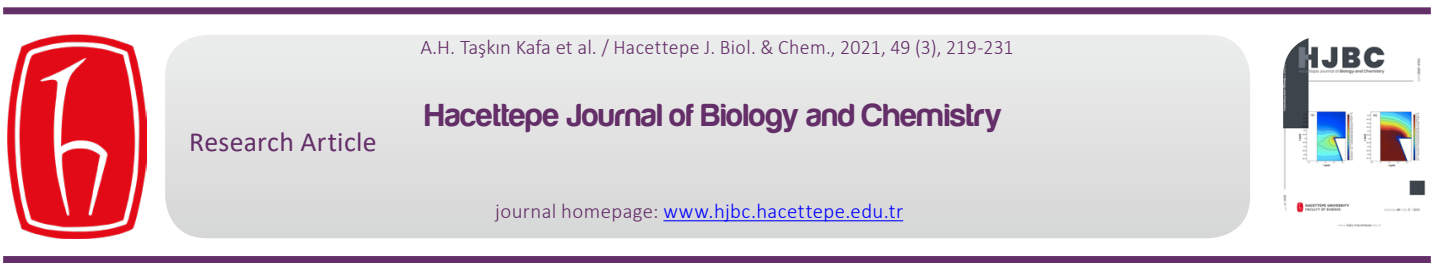

\title{
Cloning, Over-Expression, and Purification of $\beta$-Carbonic Anhydrase from an Extremophilic Bacterium: Deinococcus radiodurans
}

\section{Ekstremofilik bir bakteri olan Deinococcus radiodurans'dan $\beta$-Karbonik Anhidraz'ın klonlanması, Aşııı Ifadesi ve Saflaştırııması}

\author{
Ayşe Hümeyra Taşkın Kafa ${ }^{1^{*} \oplus}$, Arzu Coleri Cihan ${ }^{2 \odot}$, Mehmet Kuzucu $^{3 \oplus}$, Murat Cankaya ${ }^{3 \odot}$ \\ ${ }^{1}$ Cumhuriyet University, Faculty of Medicine, Department of Medical Microbiology, Sivas, Turkey. \\ ${ }^{2}$ Ankara University, Faculty of Science, Biology Department, Ankara, Turkey. \\ ${ }^{3}$ Erzincan University Faculty of Arts and Sciences Department of Biology, Erzincan, Turkey.
}

\section{ABSTRACT}

\begin{abstract}
n this study, the cloning, purification and initial characterization of carbonic anhydrase (DrCA) enzyme which we consider to be important in the resistance physiology from extremely radioresistant bacteria Deinococcus radiodurans is performed. In addition, the effect of increased gamma irradiation doses on pH-related DrCA enzyme activity was determined. DrCA activity after radiation treatment showed that the activity continuously increased by 6 fold, up to the first $800 \mathrm{~Gy}$, which a decrease in activity was observed thereafter. The maximum $\mathrm{CO}_{2}$ hydration activity for DrCA enzyme was observed at $\mathrm{pH} 7.0$ and $40^{\circ} \mathrm{C}$. DrCA enzyme, homo-dimer complex, is slightly thermostable. The activity of DrCA was significantly enhanced by several metal ions, especially $\mathrm{Zn}^{2+}$, which resulted in 5 -fold increases of $\mathrm{CO}_{2}$ hydration activity. Also sulfonamide showed inhibitory effect on the pure enzyme. The apparent $\mathrm{Km}$ and $\mathrm{Vmax}$ for $\mathrm{CO}_{2}$ as substrate were $8.4 \mathrm{mM}$ and 637 WAU/ mg for DrCA respectively. The $\mathrm{CO}_{2}$ hydration assay demonstrated that the specific activity of purified recombinant enzymes (DrCA) was significantly high.
\end{abstract}

Key Words

Deinococcus radiodurans, carbonic anhydrase, ionizing radiation.

\section{öz}

u çalışmada, radyasyona ekstrem dirençli bir bakteri olan Deinococcus radiodurans'dan direnç fizyolojisinde önemli ol-
duğunu düşündüğümüz karbonik anhidrazın (DrCA) enziminin klonlanması, saflaştırılması ve başlangıç karakterizasyonu
gerçekleştirilmiştir. Ayrıca, artan dozlarda gama radyasyonun pH ile ilişkili DrCA enzim aktivitesi üzerindeki etkisi belirlen-
miştir. Radyasyon uygulamasından sonra $\operatorname{DrCA}$ aktivitesi, $800 \mathrm{~Gy}^{\prime}$ a kadar sürekli artarak 6 kat, artmıştır, bu noktadan sonra
aktivitede azalma olduğu gözlenmiştir. DrCA enzimi için maksimum $\mathrm{CO}_{2}$ hidrasyon aktivitesi, $\mathrm{pH} 7.0$ ve $40^{\circ} \mathrm{C}^{\prime}$ de gözlenmiştir.
Homo-dimer kompleks yapısında olan $\mathrm{DrCA}$ enzimi hafif termostabildir. DrCA'nın $\mathrm{CO}_{2}$ hidrasyon aktivitesini, çeşitli metal
iyonları, özellikle $\mathrm{Zn}^{2+}$ önemli ölçüde, 5 kat artırmıştır. Ayrıca sülfonamid saf enzim üzerinde inhibe edici etki göstermiştir.
DrCA'nın substrat olarak $\mathrm{CO}_{2}$ için belirlenen Km ve Vmax değerleri sırasıyla $8.4 \mathrm{mM}$ ve $637 \mathrm{WAU} / \mathrm{mg} \mathrm{idi}^{\prime} \mathrm{CO}_{2}$ hidrasyon deneyi
saflaştırımış rekombinant enzimin (DrCA) spesifik aktivitesinin önemli ölçüde yüksek olduğunu göstermiştir.

\section{Anahtar Kelimeler}

Deinococcus radiodurans, karbonik anhidraz, iyonlaştırıcı radyasyon.

Article History: Received: Jul 20, 2020; Revised: Dec 21, 2020; Accepted: Dec 20, 2020; Available Online: May 5, 2021

DOI: https://doi.org/10.15671/hjbc.775093

Correspondence to: A.H.T. Kafa, Cumhuriyet University, Faculty of Medicine, Department of Medical Microbiology, Sivas, Turkey.

E-Mail: ahtaskin@cumhuriyet.edu.tr 


\section{INTRODUCTION}

Although radiation has detrimental effects on a large number of living groups, there are different types of microorganisms with special abilities to survive at high levels of radiation. One of these bacteria, Deinococcus radiodurans is an extremophilic bacterium with exceptional capacity to withstand severe environmental stress including dryness, oxidants, ultraviolet and ionizing radiation. This non-pathogenic and non-photosynthetic bacterium, with its ability to resist $>10,000$ Gy of ionizing radiation, has entered the Guinness records as the most resistant aerobic organism to radiation [1-5].

Carbonic anhydrases (carbonate hydrolysis, carbonate dehydratase EC 4.2.1.1) are set of common metalloenzymes that catalyze the reversible hydration of carbon dioxide to bicarbonate: $\mathrm{CO}_{2}+\mathrm{H}_{2} \mathrm{O} \leftrightarrow \mathrm{H}^{+}+\mathrm{HCO}_{3}^{-}$. $\mathrm{CO}_{2}$ hydration of carbonic anhydrase is known to be one of the fastest biocatalysis reaction in nature and has turnover numbers in million per second [6,7]. CAs have been existed in all domains of living organisms: Archaea, Eukarya and Bacteria. CAs are classified into six different groups [a, $\beta, \gamma, \delta, \zeta$, and $\eta]$. Of these six groups, $a$, $\beta$, and $\gamma$ CAs are most common and have been extensively characterized. While $\beta$-carbonic anhydrases are widespread in plants and bacteria, $\gamma$-carbonic anhydrases are usually found in archaea [8-11]. All $\beta$-CAs have an $\alpha / \beta$ fold with the core being a five-stranded $\beta$-sheet [12]. $\beta$-CAs are the most widespread enzymes all over the phylogenetic tree in microorganisms and they are not found in mammals (including humans). Furthermore, $\beta$-CAs, which also plays an important role in urea and bicarbonate metabolism, is also suggested to be important in acid resistance $[13,14]$

lonized rays decompose the water, which is the most abundant molecule in the cell. This event takes place in a very short time of 10-12 seconds, resulting in very active $\mathrm{H}^{+}$and $\mathrm{OH}^{-}$radicals. Afterward, $\mathrm{pH}$ balance and metabolic reaction continuity disappear inside the cell. A concentration of $\mathrm{H}^{+}$ions other than physiological $\mathrm{pH}$ directly affects cell metabolism, causing changes in the structure and function of cellular proteins, enzymes. Cells try to restore $\mathrm{pH}$ homeostasis using enzymatic or non-enzymatic antioxidant and $\mathrm{pH}$ stabilizer systems [15-17]. Carbonic anhydrase [CA] plays an important role in acid-base homeostasis. It catalyzes carbonic buffering, enhances intracellular $\mathrm{H}^{+}$motility, and facilitates the activity of pHi regulatory transporters $[18,19]$. The carbonic anhydrase enzyme keeps the ambient $\mathrm{pH}$ at alkaline $\mathrm{pH}$ and protects the cells against the harmful effect of the radiation against $\mathrm{pH}$ irregularity occurring in the cell with the effect of radiation. By utilizing this feature of CA, the sensitivity of cancer cells to radiation and apoptosis can be increased during radiotherapy with the use of CA inhibitors [20]. Tumor cells expressing high levels of CA have been shown to respond less to radiation, but CA inhibitors increase radiosensitivity [21].

Although CAs are very well studied, most of the work has been performed on pathogenic and thermophilic microorganism CAs. To date, $D$. radiodurans carbonic anhydrase [DrCA], which is thought to be the relationship between radiation resistance and $\mathrm{pH}$ homeostasis doesn't have been characterized. Here, we report on the cloning, purification, and initial characterization of the $\beta$-CA from the extremely ionizing radiation-resistant bacterium, $D$. radiodurans.

\section{MATERIALS and METHODS}

\section{Bacterial Strains, Culture Conditions, and Chemicals}

D. radiodurans R1 [DSM 20539 GenBank Accession number NC_001263] and Escherichia coli DH5 $\alpha$ was used for cloning were obtained from Leibniz-Institute DSMZ GmbH [DSM 6897]. The expression host E. coli BL21 [DE3] was purchased from Sigma [CM0014]. All chemicals from Sigma-Aldrich [St. Louis, MO, ABD]. D. radiodurans was grown at $32^{\circ} \mathrm{C}$ for $36 \mathrm{~h}$ in Tripton Glucose Yeast Agar [TGYA] [1\% tripton, $0.5 \%$ glucose and $0.5 \%$ yeast extract, $1.5 \%$ agar] and at $32^{\circ} \mathrm{C}$ with shaking at $175 \mathrm{rpm}$ for $10 \mathrm{~h}$ in Tripton Glucose Yeast Broth [TGYB] [1\% tripton, $0.5 \%$ glucose] at pH 6.8. PCR was performed using a Bio-Rad C1000 Touch $^{\mathrm{TM}}$ thermal cycler [BioRad] and the Pfu polymerase used in PCR reactions was purchased from Termo. Flexi Enzyme Blend, Sgfl \& Pmel restriction enzymes were purchased from Promega. $E$. coli DH5 $\alpha$ was grown on Luria Bertani [LB] medium at $37^{\circ} \mathrm{C}$ with shaking at $200 \mathrm{rpm}$. Agar plates containing $50 \mu \mathrm{g} / \mathrm{ml}, 1 \mathrm{mM}$ isopropyl-b-DD-thiogalactopyranoside [IPTG] and $20 \mathrm{mg} / \mathrm{ml}$ 5-bromo-4-chloro-3-indolyl-b-DDgalactopyrano-side [Xgal] were used for the selection of clones including recombinant vector the pFN2K [GST] [Promega].

E. coli BL21 containing recombinant pFN2K [GST] plasmid [Promega] [used for expression vector with $\mathrm{N}$ terminal GST fusion tag] was grown in Magic Media [Invitro- 
gen] used for protein induction. The protein purification was carried out using MagneGST ${ }^{\mathrm{TM}}$ Protein Purification System [Promega].

\section{Radiation application to $D$. radiodurans followed by $\mathrm{CO}_{2}$ hyration activity of DrCA}

Radiation experiments were carried out in Turkey Atomic Energy Agency Saraykoy Nuclear Research and Training Centers. D. radiodurans R1 culture was incubated at $30^{\circ} \mathrm{C}, 175 \mathrm{rpm}$ until OD600 was approximately 0.6 in the TGYB medium. The growing culture was kept in ice for 10 minutes to ensure that the cell reproductive phase remained stable. Gamma radiation doses up to 1000 Gy were applied to the tubes placed in the device three times each time, starting from 100 Gy respectively and increasing by $100 \mathrm{~Gy} .1 \mathrm{ml}$ lysis buffer [8 g / L NaCL, $0.2 \mathrm{~g}$ / L KCL, $1.44 \mathrm{~g} / \mathrm{L} \mathrm{Na}_{2} \mathrm{HPO}_{4}, 0.24 \mathrm{~g} / \mathrm{L} \mathrm{KH}_{2} \mathrm{PO}_{4}, 1 \mathrm{mM} \mathrm{PMSF}$ $11.494 \mathrm{ml} 87 \%$ glycerol, $0.0943 \mathrm{ml}$ Triton-X100 and 0.2 $\mathrm{mg} / \mathrm{ml}$ lysozyme] on pellet centrifuged at $20000 \mathrm{xg}$ for 10 minutes after application of doses. Samples kept on ice for 20 minutes were sonicated with ultrasonic [Sonics Vibra Cell VCX750]. Sonication was performed in $35-45 \%$ amplitude as 20 seconds "on" 15 seconds "off" for a total of 5 minutes. After sonication, drCA activity was measured by centrifuging again and supernatant was taken and an activity curve was created.

\section{PCR Amplification and Cloning of D. radiodurans $\beta-C A$}

$D$. radiodurans R1's genetic sequence [GenBank accessory number: AE000513.1], the gene coded DR_2238 belonging to $\operatorname{DrCA}$, which is included in the $\beta$ family, has been designed according to the base sequence in the database of $\mathrm{NCBI}$ [National Center for Biotechnology Information]. Gene-specific primers were designed previously and synthesized by Flexi Vector Primer Design Tool online program. Primers designed with this tool were investigated in the $D$. radiodurans $\mathrm{R} 1$ genome with BLAST [Basic Local Alignment Search Tool].The gene encoding for $\beta-C A$ was amplified using primers FLEXY Forward [Dr_2238_F] 5'GCGTGCGATCGCCATGGGGCG3' and FLEXY Reverse [Dr_2238_R] 5'CGAGGTTTAAACTTAGAGTGC3' [Underlines indicate restriction enzyme sites]. The PCR reaction mix and cycle sequenceis detailed in table The resulting 795 bp product for $\beta-C A$. PCR

b

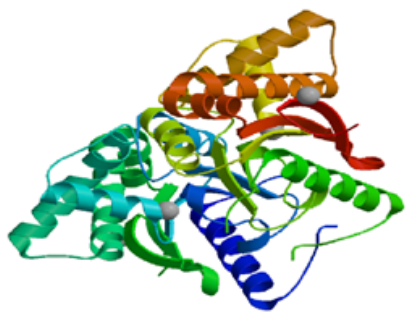

C

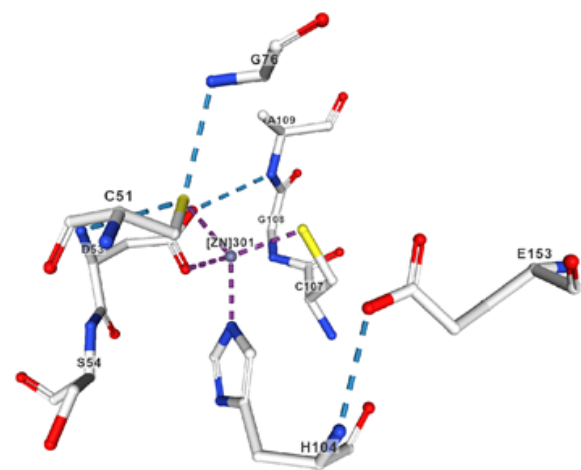

Figure 1. Predicted secondary and tertiary structure of D. radiodurans isolate carbonic anhydrase. [A] Predicted secondary structure of DrCA. Using PSIPRED, the secondary elements in the protein were predicted to consist of nine $\alpha$-helices and five $\beta$-sheets [B] Ribbon structure and $[\mathrm{C}]$ stick of homology model predicted using SwIss-Model. Potential hydrogen bonds are represented as blue, halogen bonds are as turquoise, hydrophobic contacts are as grey, pi interactions are as orange and yellow. DrCA active site showing the zinc ion interactions are as purple. 


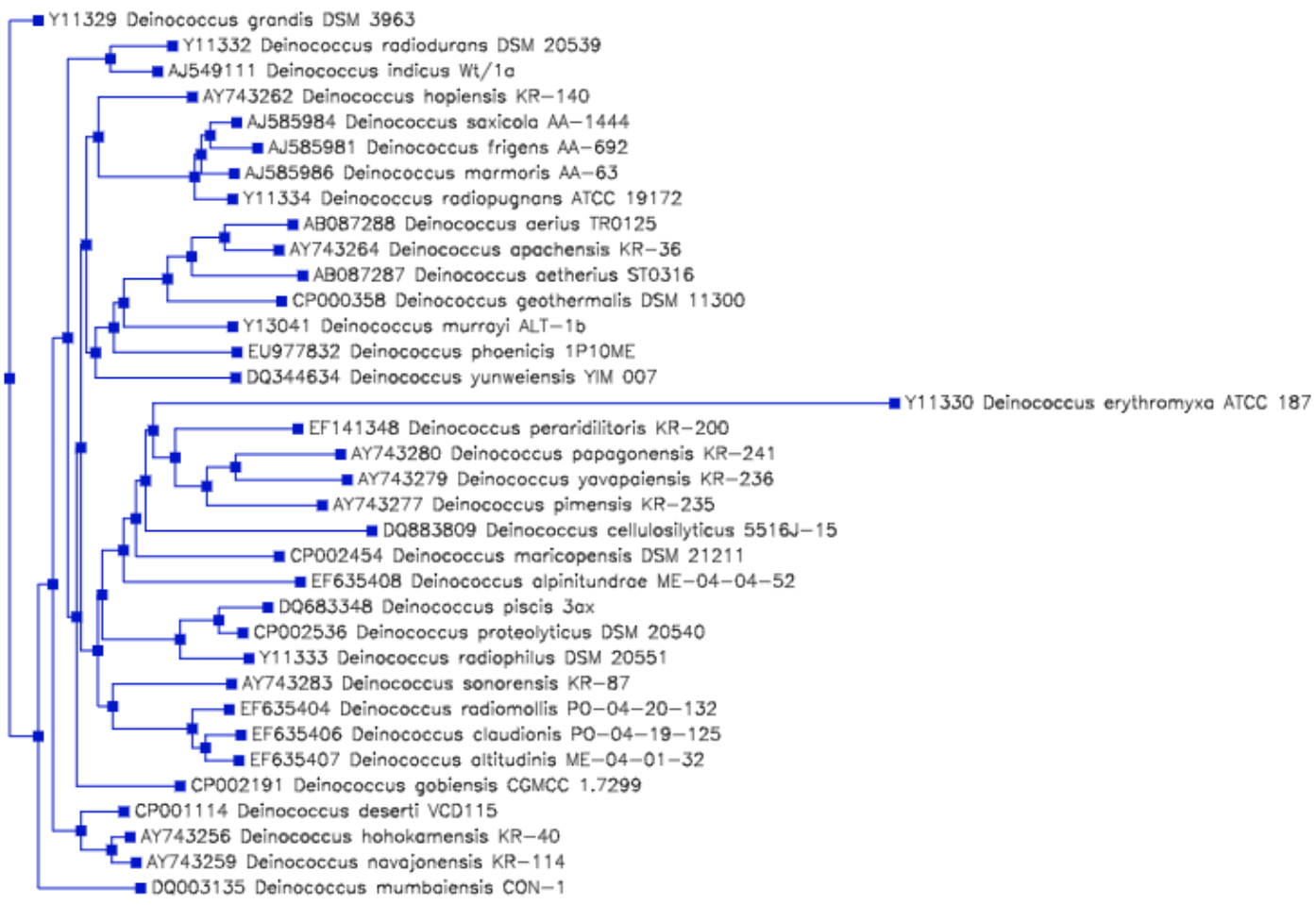

Figure 2. Phylogenetic tree of the genus Deinococcus [http://www.straininfo.net/]

products were digested using $S g f l$ and $P$ mel restriction enzymes $1 \mathrm{~h}$ at $37^{\circ} \mathrm{C}$. After restriction digest, the PCR products were ligated with pFN2K Flexi vector. Ligation was performed using T4 DNA ligase [New England Biolabs] $1 \mathrm{~h}$ at $25 \circ \mathrm{C}$. The ligations were then combined with calciumchloride- competent E. coli $\mathrm{DH} 5 \alpha$ and E. coli BL21[DE3] cells, and transformations were done using the electroporation. Ligated plasmids were purified from the transformants using a Gen Elute HP Plasmid purification Kit and the presence of CA genes in the plasmids was confirmed by gene sequencing using cloning primers.

\section{Over-Expression of DrCA and SDS-PAGE Analysis}

Over-expression of the CAs was carried out by transferring the recombinant plasmid containing $\beta-C A$ to the $E$. coli BL21[DE3] expression strainand the transformants were then inoculated in MagicMedia E. coli expression medium grown $18 \mathrm{~h}$ at $30{ }^{\circ} \mathrm{C}$ with shaking [200 rpm]. Simple protocol eliminates time-consuming OD monitoring and induction steps. The overnight cultures were used to inoculate $15 \mathrm{ml}$ flasks containing $1 \mathrm{ml}$ of Magic media, and the cultures were incubated $18 \mathrm{~h}$ at $30^{\circ} \mathrm{C}$ with shaking [200 rpm] following the manufacturer's instructions. After incubation, the cells were harvested by centrifugation $\left[15.000 \mathrm{~g}, 5 \mathrm{~min}\right.$ at $4^{\circ} \mathrm{C}$ ], and the cell pellets were stored at $-20^{\circ} \mathrm{C}$ until use. Frozen pellets containing CA proteins were thawed in an ice-bucket filled with ice and then suspended with MagneGST lysis buffer [This buffer supplemented with $10 \mathrm{mg} / \mathrm{ml}$ lysozyme solution prepared in $25 \mathrm{mM}$ Tris $\mathrm{HCl}$ ]. 100 $\mu$ lysis buffer for $\mathrm{OD}_{600}=1$ and $300 \mu$ lysis buffer for $\mathrm{OD}_{600}=3$ were added. After $2 \mu \mathrm{DN}$ Dse free RNAase was added. The resuspended pellets were lysed with shaking for 30 minutes at room temperature. Then pellets were distrupted by ultrasonication for $15 \mathrm{~s}$ with a $5 \mathrm{~s}$ break [pellets were kept on ice] at 35-45\% amplitude [Sonics Vibra Cell VCX75020]. An aliquot of lysed cells was divided as total protein, and the remaining lysate was centrifuged for 60 minutes at $15.000 \mathrm{rpm}$ at $0^{\circ} \mathrm{C}$. the supernatant was reserved for SDS-PAGE. A small portion of the supernatant containing soluble proteins was transferred to a new Eppendorf tube, and the remaining supernatant was used for protein purification. All protein fractions were mixed with Laemmli loading buffer and separated in $12 \%$ SDS PAGE. Then gel was stained with commasie brilliant blue dye to make the proteins visible. 


\section{Purification of Over-expressed $\beta-C A$ from $D$. radiodurans}

Small-scale purification of $\beta$-CA was carried out using MagneGST'M Protein Purification System following manufacturer's instructions. MagneGST ${ }^{\text {TM }}$ Glutathione Particles were added directly to the cleared or crude lysate. GST-fusion proteins bound to the particles during incubation at $4^{\circ} \mathrm{C}$ and then were three times washed to remove unbound and nonspecifically bound proteins.

GST-fusion protein is eluted from the particles with 10-50 mM reduced glutathione at $\mathrm{pH}$ 8. The presence of proteins in the elutions was confirmed by SDS-PAGE. After purification of GST-fusion protein, the undesirable GST tag was cleaved by Pro-TEV Plus protease. Pro-TEV protease specifically cleaves the sequence Glu-AsnLeu-Tyr-Phe-GIn- $\downarrow$-[Gly/Ser] [22].

ProTEV Plus has an $\mathrm{HQ}$ tag at the N-terminus. After cleaving the fusion protein, ProTEV Plus was removed from the reaction mix by incubating with MagneHis ${ }^{\mathrm{TM}}$ $\mathrm{Ni}$-Particles. Protein concentration was determined by the Lowry method.

\section{Assay of DrCA activity}

Enzymatic activity of DrCA was measured using $\mathrm{CO}_{2}$ hydration assay and presented as Wilbur-Anderson units [WAU]. As a result of $\mathrm{CO}_{2}$ hydration activity bicarbonate ions and protons are formed, and the resulting $\mathrm{pH}$ change is monitored using bromothymol blue as an indicator. The indicator is yellow at $\mathrm{pH}$ less than 6.2 and blue when $\mathrm{pH}$ is higher than 8.3.

Briefly, reaction mixture was prepared by adding $10 \mu \mathrm{l}$ CA enzyme, $1 \mathrm{~mL}$ of ice-cold $20 \mathrm{mM}$ Tris- $\mathrm{SO}_{4} \mathrm{pH} 8.3$ containing $0.2 \mathrm{~g} \mathrm{~L}^{-1}$ bromothymol blue was kept on ice. The reaction was initiated by adding $1 \mathrm{~mL}$ of ice-cold $\mathrm{CO}_{2}$-saturated water. The bovine CA [BCA] was used as positive control. The DrCA activity was determined and expressed in Wilbur-Anderson Units per mg of the enzyme. WAU is identified with $\left[\mathrm{t}_{0}-\mathrm{tc}\right] / \mathrm{tc}$. The time interval $\left[\mathrm{t}_{0}\right.$ and $\mathrm{tc}$ ] represented the time required for the $\mathrm{pH}$ value to drop from blue $[\mathrm{pH} 8.3]$ to yellow $[\mathrm{pH}$ 6.2] at $0^{\circ} \mathrm{C}$ in the absence and presence of $\mathrm{CA}$, respectively. $\mathrm{CO}_{2}$-saturated solution was prepared by treating $\mathrm{CO}_{2}$ into pure water on ice bath for at least 30 minutes. All activity measurements were done in triplicates.
Increasing concentrations of $\mathrm{CO}_{2}$ were used to define the kinetic properties of DrCA. Serial dilutions of icecold CO2 non-saturated solution from 10 to $60 \mathrm{mM}$ were prepared using ice-cold $\mathrm{CO}_{2}$ saturated solution [70 mM]. DrCA activities at different $\mathrm{CO}_{2}$ concentrations were determined. The kinetic parameters of $\mathrm{Km}$ and Vmax were achieved with the use of Michaelis-Menten equation.

\section{RESULTS and DISCUSSION}

Many studies have been conducted in detail on carbonic anhydrase of pathogenic or non-pathogenic microorganisms until recently [23]. However, a study on carbonic anhydrase of a microorganism with high radiation resistance is not available in the literature. In a recent study investigating the effect of radiotherapy on cancer cells, it was seen that inhibition of the enzyme carbonic anhydrase IX (CAIX) in tumor cells caused a decrease in intracellular $\mathrm{pH}$ values and increased cell death. These results suggest that the active CAIX enzyme protects cells against radiation by maintaining the alkaline $\mathrm{pH}[24,25]$. Because of investigation of enzymes and proteins that can resist $\mathrm{pH}$ irregularity occurring in the cell with the effect of radiation, especially in this type of extremophilic organisms, is important in clarifying the resistance physiology. The studies focused on CA, which is thought to have an important place in prokaryotic physiology, are important for determining the new functions of this enzyme and the role of CAs in extremophilic bacteria is thus beginning to be better understood.

\section{Searching putative carbonic anhydrase of $D$. radiodurans $\mathbf{R} 1$}

Physicochemical parameters of DrCA such as number of amino acid, molecular weight, theoretical isoelectric point, amino acid composition, instability index, aliphatic index, Grand Average of Hydropathicity [GRAVY] were described by Expasy ProtParam tool [https://web. expasy.org/protparam/] [26].

Locus NP_295960.1 from the DrCA genome consists of 795 nucleotides, encoding a 264-amino-acid protein with a theoretical molecular mass of $28.7 \mathrm{kDa}$ and isoelectric point of 5.39. So it seemed strongly acidic protein. 


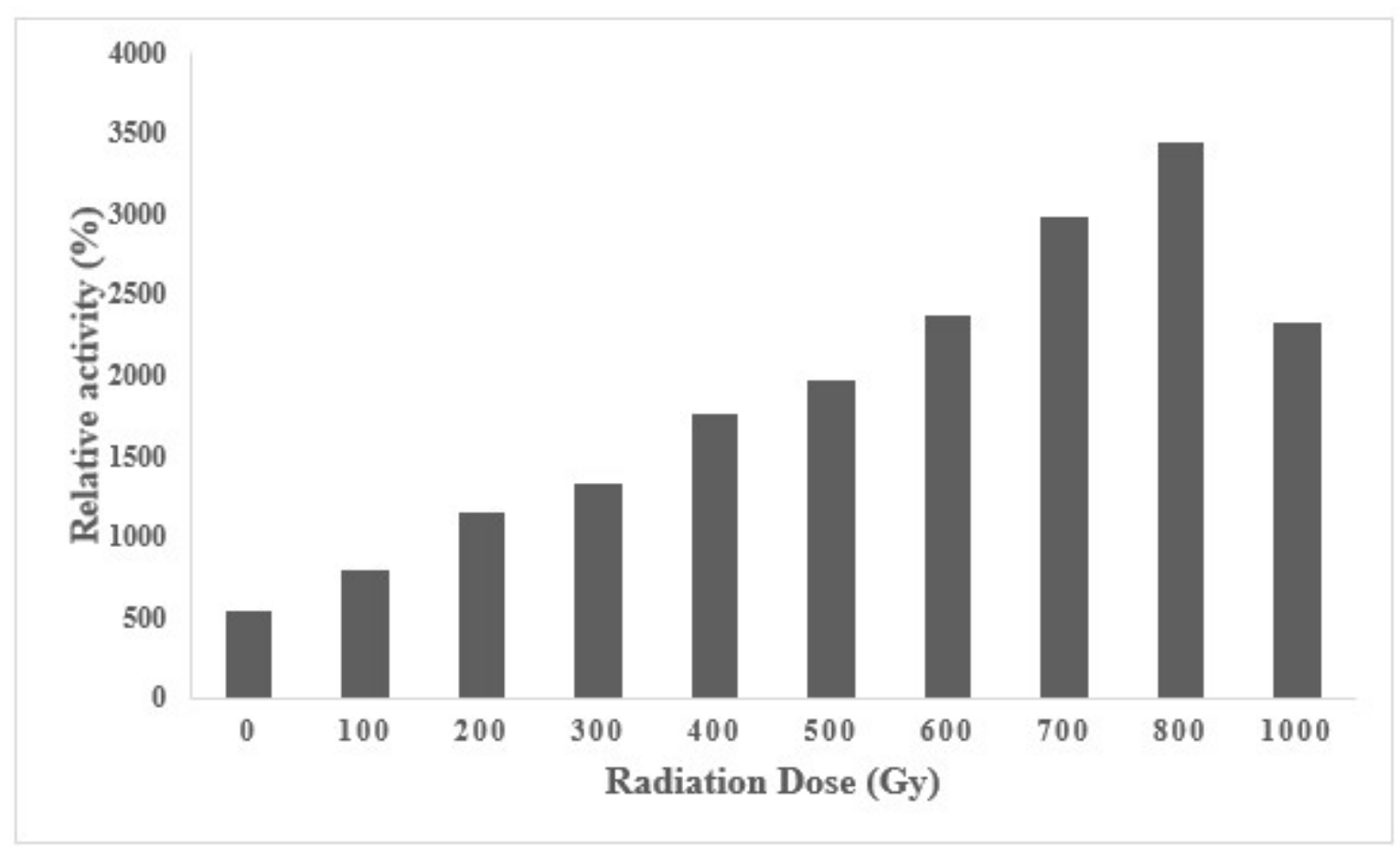

Figure 3. $\operatorname{DrCA~CO}$, hydration activity of $D$. radiodurans exposed to certain doses of gamma radiation [Gy].

The $D$. radiodurans sequence composed of 36 negatively charged residues [Asp + Glu] and 30 positively charged residues [Arg + Lys] and the comparatively high percentage [12.5\%] of amino acid present is alanine. The instability index is computed to be 52.21 . This classifies the protein as unstable. $D$. radiodurans had a CA protein with aliphatic index of 100.19 which positively indicates the thermostability of CA protein. Aliphatic index plays role in protein thermal stability. Proteins with a high aliphatic index which suggested that are thermostable. [27]. The GRAVY of CA protein is negative for $D$. radiodurans [-0.134] which indicates hydrophilicity of DrCA protein in nature. The low GRAVY range indicates the possibility better interaction of protein and water $[28$, 29].

The physiochemical properties of the DrCA were predicted using amino acid sequence comparable to previous studies [30-32].

While characterizing the CA of Bacillus safensis, as an Leu rich protein in which positively charged amino acid residues were dominant. Moreover, the enzyme was classified as unstable according to the instability index and aliphatic index was high which indicates the thermostability of CA protein as in this study [33].
Comparative amino acid sequence analyses showed that the predicted DrCA amino acid sequence identity and cluster with distinct sets of homologues. The CDD prediction placed DrCA in clade $C$ [cd03378] of $\beta$-class CAs. A homology search performed using Basic Local Alignment Search Tool [BLAST, http://blast.stva.ncbi.nlm.nih. gov/Blast.cgi] revealed that the amino acid sequence of D. radiodurans CA shares $39.47 \%$ identity with Mycobacterium tuberculosis variant bovis AF2122/97 CA protein [GenBank: YP_009360978.1], 38.31\% identity with Synechocystis sp. [GenBank: WP_010873497.1], 37.19\% identity with Streptomyces coelicolor A3[2] [GenBank: NP_627913.1], 35.29\% identity with Microcystis aeruginosa [GenBank: WP_012264892.1], 33.95\% identity with Schizosaccharomyces pombe [GenBank: NP_596512.2].

The CA secondary structure predicted using PSIPRED (Figure 1A). The CA secondary protein structure prediction result showed that the protein has $44 \% \alpha$ helical [9 helices; 96 residues] $14 \% \beta$ sheet [5 strands; 32 residues]. The $\beta$-CAs common function as dimers or larger multi-oligomeric states. They have a compact structures with a $\beta$-sheet core composed of 5 anti-parallel strands with 4 or more ahelices and a shallow [34]. 
Homology model of the DrCA protein was predicted using SWISS-MODEL [http://swissmodel.expasy.org] server (Figure 1B). Based on the template search about 50 templates were recommended. About templates with higher identity were selected for model production. The property of the predicted model was analyzed using PROSA web server [https://prosa.services.came. sbg.ac.at/prosa.php]. The models predicted using the template $1 y m 3$ with high fidelity regions of amino acid residues in Ramachandran Plot [http://eds.bmc.uu.se/ ramachan.html] and Z-score was chosen. The molecular surface of the forecasting model was described in figure $1 C$. DrCA protein has a compact structure with a $\beta$-sheet core with anti-parallel strands, $\alpha$-helices. The enzyme tertiary structure has been found to contain zinc ions at these active sites and the enzyme exists as homo-dimer structure.

\section{Systematic Position and Phylogeny}

As of 2019, there were 79 species of Deinococcus described according to LPSN database [http://www.bacte- rio.net/]. Phylogenetic tree constructed as a result of phylogenetic analysis of Deinococcus 16S rRNA gene sequences is shown in Figure 2.

\section{$\mathrm{CO}_{2}$ hyration activity of DrCA in $D$. radiodurans exposed to radiation}

Exposure to ionizing radiation induces a dose-dependent $\mathrm{CO}_{2}$ hydration activity increase in $D$. radiodurans cells. DrCA activity is constantly increasing up to 800 Gy. After $800 \mathrm{~Gy}$, It is observed that the activity decreased. As shown in figure 3, gamma radiation doses could activate and enhance $\mathrm{CO}_{2}$ hydration activity of DrCA, especially 800 Gy, which significantly increased $\mathrm{CO}_{2}$ hydration activity to $3440 \%$ when compared to that of control. $\mathrm{CO}_{2}$ hydration activity was observed as $540 \%$ in the non-radiation control group.

These results indicate that the DrCA enzyme can protect the cell against the metabolism regularity due to radiation and that $D$. radiodurans bacteria has an important place in radiation resistance.

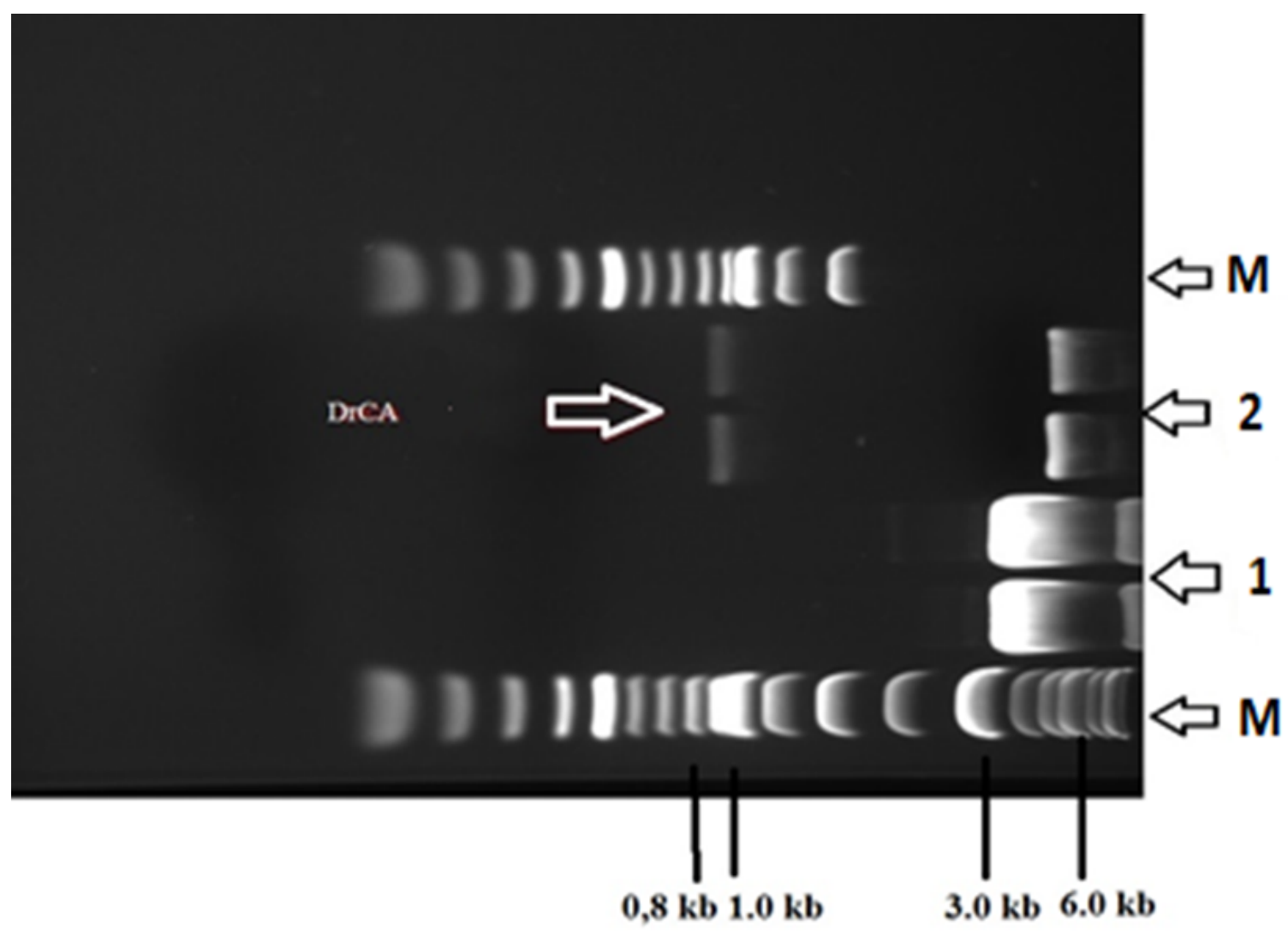

Figure 4. The electrophoresis diagram of pFN2K [GST]/DrCA and digestion with Sgfl and Pmel. M: Marker, DNA ladder. Lane 1: pFN2K [GST]/DrCA; Lane 2: pFN2K [GST]/DrCA digested by Ndel and Xhol. 


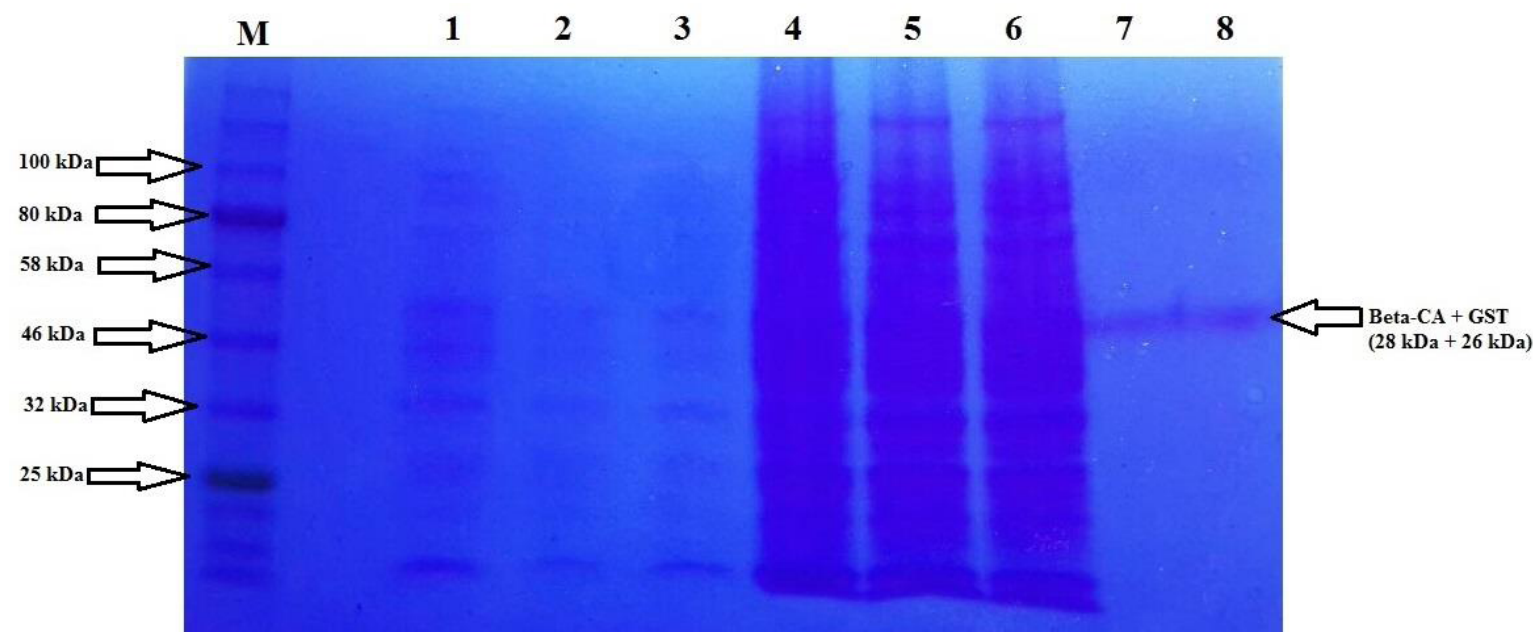

Figure 5. 12\% SDS-PAGE analysis of DrCA expression. The molecular weight of fusion protein is between $54 \mathrm{kDa}$. Lanes: M: Marker [New England Biolabs, P7712S], 1-3 Elutions, 4-6: Lysate, 7-8: Purified GST-tagged fusion protein by Magne-GST

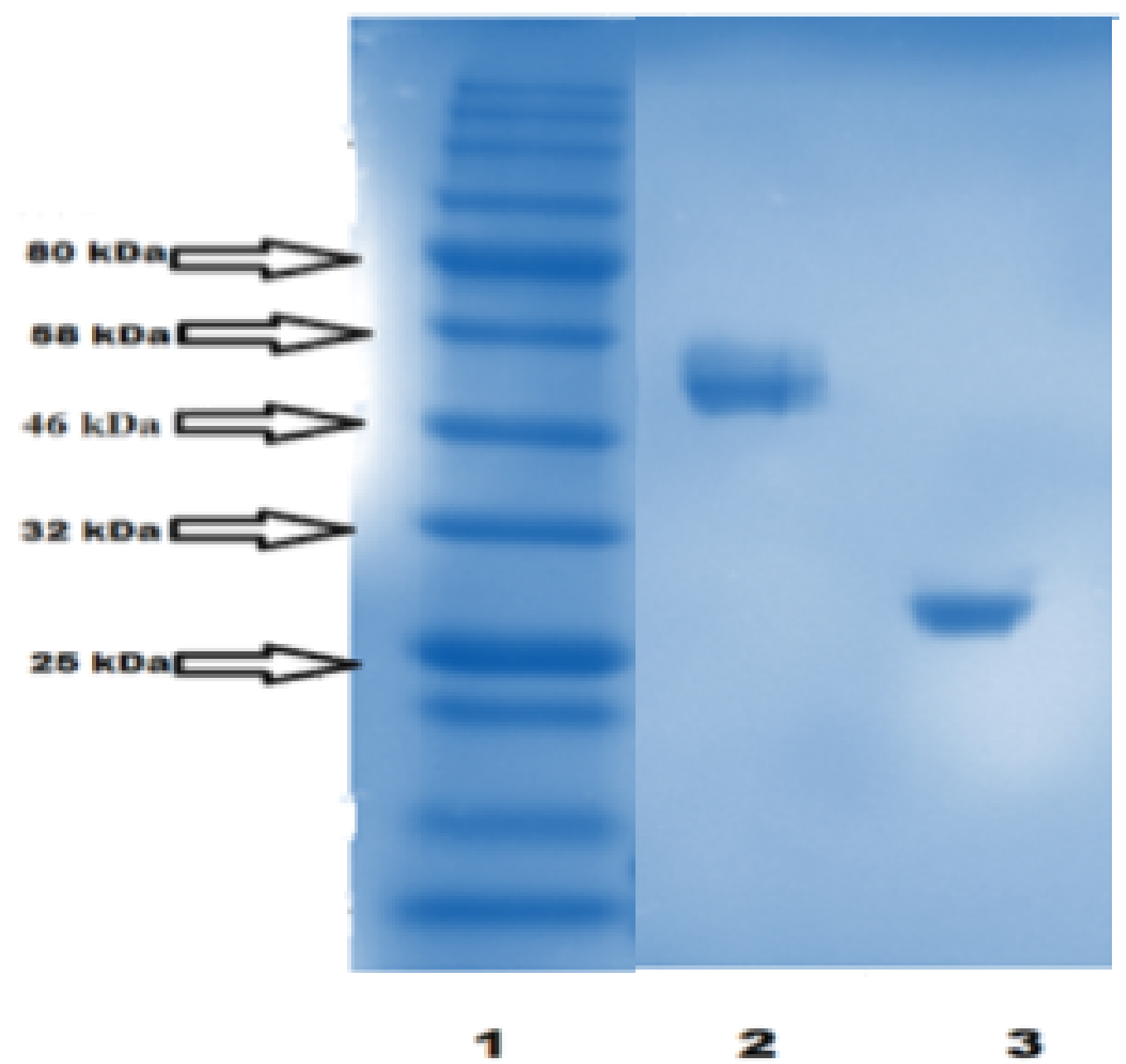

Figure 6. SDS-PAGE [12\%] analysis of GST-DrCA fusion protein after cleavage by TEVp. Lane 1: Marker, Protein Ladder; Lane 2: The purified GST-DrCA fusion protein; Lane 3: The purified DrCA peptide by MagneHis ${ }^{\mathrm{TM}} \mathrm{Ni}$-Particles. 


\section{Construction of recombinant pFN2K [GST]/DrCA plasmid for protein expression}

In order to construct expression plasmid of pFN2K [GST] Flexi $^{\circledR}$ vector according to DrCA gene sequence, the DrCA gene was amplified by PCR and sequenced with the expected length of 820-bp DrCA sequence [including restriction enzyme cutting sites] and then cloned into the pFN2K [GST] Flexi ${ }^{\circledR}$ vector digested by Sgfl and Pmel to obtain recombinant pFN2K/DrCA plasmid for protein expression (Figure 4).

\section{Expression of recombinant DrCA protein}

The recombinant pFN2K [GST]/DrCA plasmid was transformed into E. coli BL-21 [DE3] strain grown on MagicMedia $^{\mathrm{TM}}$ E. coli expression medium was grown $18 \mathrm{~h}$ at 30 ${ }^{\circ} \mathrm{C}$ with shaking [200 rpm]. The DrCA was produced as a fusion protein with a glutathione tag at its $\mathrm{N}$-terminus. A band with an approximately $54 \mathrm{kDa}$ from the cell culture grown MagicMedia in 12\% SDS-PAGE was observed, which is consistent with the expected molecular mass of DrCA fusion protein (Figure 5).

\section{TEV cleavage and purification of DrCA peptide}

To produce recombinant DrCA peptide, the purified fusion protein GST-DrCA was treated with Pro-TEVp. Quite efficient cleavage was performed in standard buffer at $20 \mu \mathrm{g}$ fusion protein four unit TEVp at $30^{\circ} \mathrm{C}$ overnight. TEV cleavage of the DrCA peptide from the GST fusion protein resulted in release of DrCA with a native $\mathrm{N}$-terminal Methionine. A band, total protein 54 kDa [GST-tag 26 kDa+DrCA 28 kDa] is clearly confirmed in the SDS-PAGE. After the TEV cleavage, the DrCA peptide was successfully separated from the reaction product by MagneHis ${ }^{\text {TM }} \mathrm{Ni}$-Particles. Purified DrCA protein concentration was determined by Lowry protein assay as $165 \mu \mathrm{g} / \mathrm{mL}$. To verify the purity of DrCA protein, SDS PAGE was applied and displayed single band close to 28 $\mathrm{kDa}$ in good agreement with the determined molecular weight of $28 \mathrm{kDa}$ (Figure 6).

\section{Effects of Temperature and pH on the Activities of DrCA}

The effects of temperature on the activities of DrCA was measured in the range of $0-70{ }^{\circ} \mathrm{C}$. The results presented in figure $7 \mathrm{~A}$ showed that the optimal temperature for $\mathrm{CO}_{2}$ hydration activities of $\operatorname{DrCA}$ was $40^{\circ} \mathrm{C}$. A rapid decrease in $\mathrm{CO}_{2}$ hydration activities of $\mathrm{DrCA}$ was observed in the range of $40^{\circ} \mathrm{C}-70^{\circ} \mathrm{C}$. The $\mathrm{pH}$ effects on $\mathrm{CO}_{2}$ hydration activities of DrCA was determined in the range of $6.25-8.25$ at $40^{\circ} \mathrm{C}$ using HEPES-NaOH buffer. As shown in figure 7B, the optimum $\mathrm{pH}$ for DrCA activity was found to be 7.0, which was similar to the optimal $\mathrm{pH}$ values of other CA varieties [3538] Many other factors, including buffer and ion concentration, affect activity, which making it difficult to compare activity measurements of CAs [12]

More than $40 \%$ of DrCA residual activity could be retained in the $\mathrm{pH}$ 8.0. The Bovine erythrocyte CA exhibited activity in the $\mathrm{pH}$ range of 6.5-8.0 and temperature range of $30-40^{\circ} \mathrm{C}$.

\section{Thermostability Test}

For the determined of stability, the purified DrCA was preincubated at $7 \mathrm{~h}$ in $0.025 \mathrm{M}$ Hepes buffer [pH 7.0] at $10-70^{\circ} \mathrm{C}$. The purified protein solution was prepared to be approximately $1 \mathrm{mg} / \mathrm{ml}$. Enzyme activity was measured under the standard condition and that is without any treatment was taken as $100 \%$.

Rapidly decreasing $\mathrm{CO}_{2}$ hydration activities of DrCA was observed in the range of $40^{\circ} \mathrm{C}-70^{\circ} \mathrm{C}$. Less than $40 \%$ of the maximum DrCA activity was retained beyond $55^{\circ} \mathrm{C}$. DrCA protein is slightly thermostable and was completely inactivated in $10 \mathrm{~s}$ at $70^{\circ} \mathrm{C}$

Radiation-resistant organisms need proteins with high thermostability that can withstand the significant temperature fluctuations occurring in the cell under the influence of ionizing radiation. Therefore, it is an expected feature of DrCA to be a thermostable enzyme.

\section{Effects of Metal lons and Sulfonamide on the Activities of DrCA}

The effects of metal ions including $\mathrm{Na}^{+}, \mathrm{Mn}^{2+}, \mathrm{Fe}^{3+}, \mathrm{Zn}^{2+}$, $\mathrm{Ca}^{2+}, \mathrm{Mg}^{2+}$ and Sulfonamide on $\mathrm{CO}_{2}$ hydration activities of DrCA were investigated at the concentration of 0,5 mM. As shown in figure $8, \mathrm{CO}_{2}$ hydration activity of DrCA was activated and enhanced by all tested metal ions, especially $\mathrm{Zn}^{2+}$, which significantly increased $\mathrm{CO}_{2}$ hydration activity to $500 \%$ when compared to control. Sulfonamide which significantly decreased $\mathrm{CO}_{2}$ hydration activity to $20 \%$ when compared to that of no ion control. These results showed that $\mathrm{Zn}^{2+}$ was the most effective cation for DrCA activity. Because zinc is needed for catalytic activity in $\beta$-CAs [39]. Although sulfanamide and its derivatives have been shown to cause inhibition of CAs belonging to pathogenic microorganisms [40-43], it has been demonstrated in this study that $D$. radiodurans $\beta$-CA could also be targeted by sulfonamide inhibitors. 

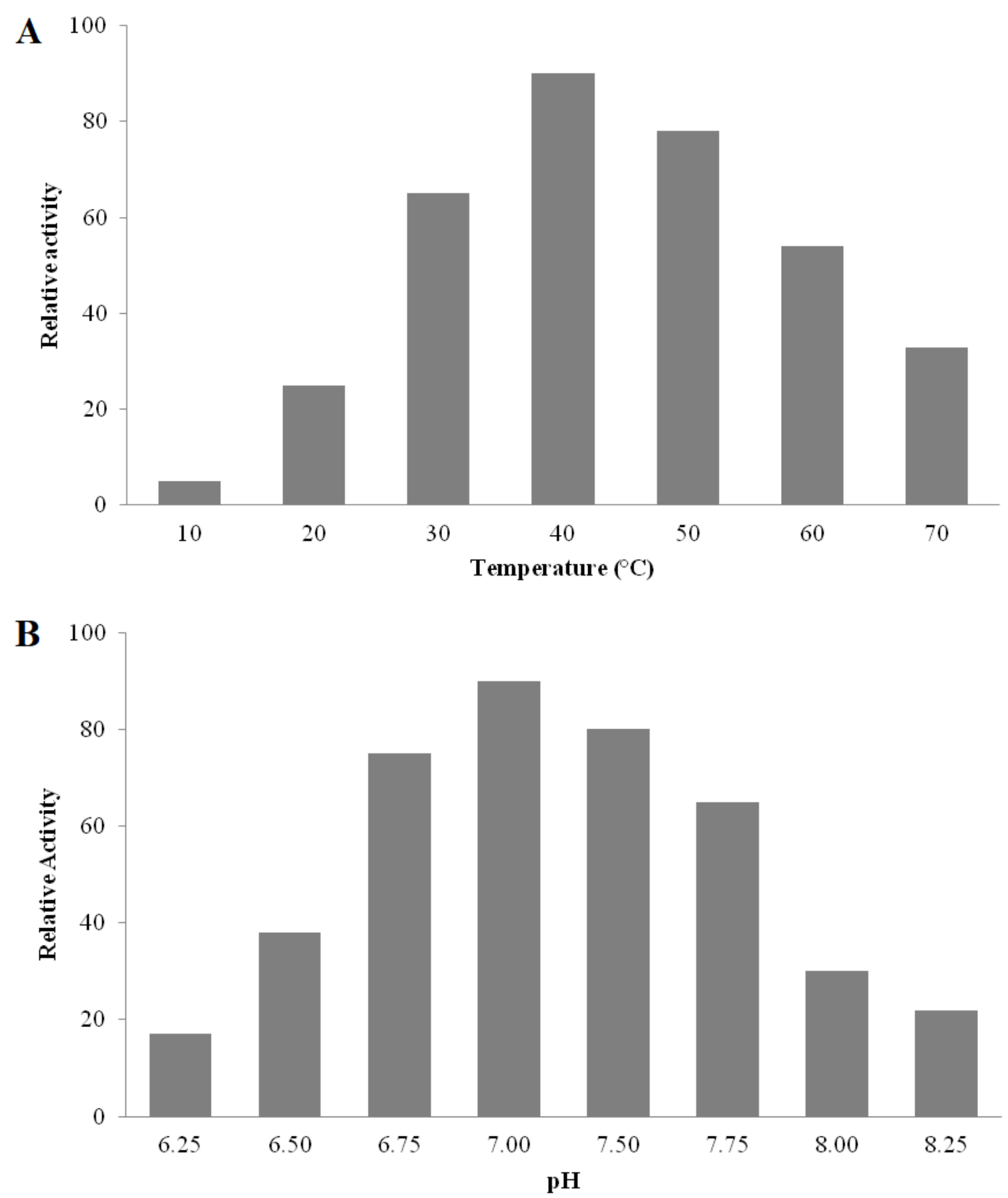

Figure 7. Effects of temperature and $\mathrm{pH}$ on the hydration activities of $\operatorname{DrCA}[\mathrm{a}, \mathrm{b}]$. [A] Relative activity at different temperatures; $[\mathrm{B}]$ Relative activity at different $\mathrm{pH}$ conditions. 


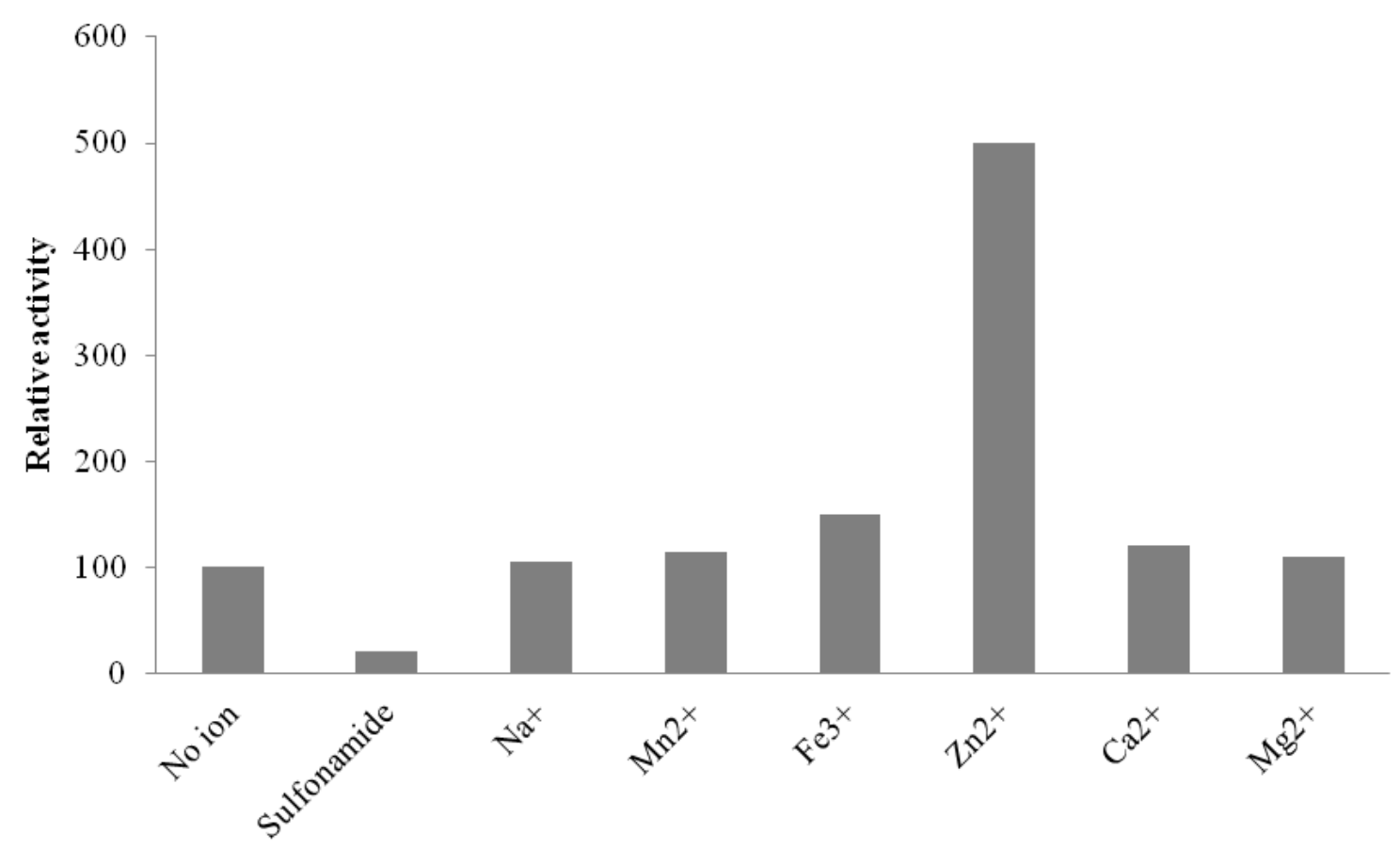

Figure 8. Effects of metal ions on $\mathrm{CO}_{2}$ hydration activities of DrCA.

Table 1. Comparison of $\beta$-carbonic anhydrase $[\beta-C A]$ hydration activities between $\operatorname{DrCA}$ and several published CA enzymes.

\begin{tabular}{ccc}
\hline Species & $\begin{array}{c}\mathrm{CO}_{2} \text { hydration activity } \\
{[\mathrm{WAU} / \mathrm{mg}]}\end{array}$ & References \\
\hline Chlamydomonas reinhardtii [CAH7] & 3.1 & 39 \\
\hline Chlamydomonas reinhardtii [CAH8] & 4.2 & 39 \\
\hline Serratia marcescens Wy064 [CA1] & 165 & 40 \\
\hline Serratia marcescens Wy064 [CA3] & 234 & 40 \\
\hline Pseudomonas aeruginosa [CA1] & 401 & 41 \\
\hline Pseudomonas aeruginosa [CA2] & 21 & 41 \\
\hline Bacillus subtilis & 714 & 42 \\
\hline Deinococcus radiodurans R1 & 637 & This Study
\end{tabular}




\section{Kinetics Parameter Assays}

To measure the kinetic parameters of enzyme reaction mixtures were prepared with the substrate concentration of $\mathrm{CO}_{2}$ varied from 10 to $60 \mathrm{mM}$. The Michaelis-Menten equation for hydration of $\mathrm{CO}_{2}$ to $\mathrm{HCO}^{3-}$ was determined by using the nonlinear regression method and then $\mathrm{Km}$ and $\mathrm{Vmax}$ values were calculated as $8.4 \mathrm{mM}$ and 637 WAU / mg for DrCA respectively. DrCA showed extracellular high activity. Comparison of several CAs reported in previous studies and DrCA hydration activities were presented in Table 1. These results meant there could be some variation in the structure of DrCA [44-47].

\section{CONCLUSIONS}

In this study, the cloning, purification and initial characterization of $\beta$-CA enzyme from extremely ionizing radiation resistant bacteria $D$. radiodurans was performed. $\mathrm{Km}$ and $\mathrm{Vmax}$ values of DrCA enzyme were determined as $8.4 \mathrm{mM}$ and $637 \mathrm{WAU} / \mathrm{mg}$, respectively. And enzyme is slightly thermostable.

As a result, with this study, it has been shown that CA enzyme has an prospective role in the resistance against extramophilic D.radiodurans bacteria against high dose radiation. Any study investigating the purification of new CA isozymes and classes, their catalytic activities and mechanisms will contribute to closing the information gap in this regard.

\section{Acknowledgement}

The work was completed with the financial support of Erzincan University Scientific Research Projects Management Unit. (project no. Science-A-080715-0153).

\section{References}

1. A.W. Anderson, H.C. Nordon, R.F. Cain, G. Parrish, D.E Duggan et al., Studies on a radioresistant micrococcus: I. Isolation, morphology, cultural characteristics and resistance to gamma radiation, Food Technol., 10 (1956) 575-578.

2. D.E Duggan, A.W. Anderson, P.R. Elliker, R.F. Cain, Ultraviolet exposure studies on a gamma radiation resistant micrococcus isolated from food ${ }^{a, b, c}$, J. Food Sci., 24 (1959) 376-382.

3. V. Mattimore, J.R. Battista, Radioresistance of Deinococcus radiodurans:functions necessary to survive ionizing radiation are also necessary to survive prolonged desiccation, J. Bacteriol., 178 (1996) 633-637.

4. J.R. Battista, Against all odds: the survival strategies of Deinococcus radiodurans, Annu. Rev. Microbiol., 51 (1997) 203-224.

5. M.M. Cox, J.R. Battista. Deinococcus radiodurans-the consummate survivor, Nat. Rev. Microbiol., 3 (2005) 882892.

6. O. Alvizo, L.J. Nguyen, C.K. Savile, J.A. Bresson, S.L. Lakhapatri, et al., Directed evolution of an ultrastable carbonic anhydrase for highly efficient carbon capture from flue gas, Proc. Natl. Acad. Sci. U. S. A., 111 (2014) 1643616441.

7. C. Capasso, C.T. Supuran, An overview of the alpha-, betaand gamma-carbonic anhydrases from Bacteria: can bacterial carbonic anhydrases shed new light on evolution of bacteria?, J. Enzyme Inhib. Med. Chem., 30 (2015) 325332.

8. S.K. Smith, J.G. Ferry, Prokaryotic carbonic anhydrases, FEMS Microbiol. Rev., 24 (2000) 335-366.

9. A. Di Fiore, V.A. Iterio, S.M. Monti, G. De Simone, K. D'Ambrosio, Thermostable Carbonic Anhydrases in Biotechnological Applications, Int. J. Mol. Sci., 16 (2015) 15456-15480.

10. C. Capasso, C.T. Supuran, An overview of the alpha-, betaand gamma-carbonic anhydrases from Bacteria: can bacterial carbonic anhydrases shed new light on evolution of bacteria?, J. Enzyme Inhib. Med. Chem., 30 (2015) 325332.

11. A. Aspatwar, S. Haapanen, S. Parkkila, An Update on the Metabolic Roles of Carbonic Anhydrases in the Model Alga Chlamydomonas reinhardtii, Metabolites, 13 (2018).

12. Covarrubias AS, Larsson AM, Hogbom M, Lindberg J, Bergfors T, Bjorkelid C, Mowbray SL, Unge T, Jones TA. Structure and function of carbonic anhydrases from Mycobacterium tuberculosis, J. Biol. Chem., 280 (2005) 18782-18789.

13. Maresca A, Carta F, Vullo D, Supuran CT Dithiocarbamates strongly inhibit the $\beta$-class carbonic anhydrases from Mycobacterium tuberculosis, J. Enzyme Inhib. Med. Chem., 28 (2013) 407-411.

14. F.N. Stahler, L. Ganter, K. Lederer, M. Kist, and S. Bereswill. Mutational analysis of the Helicobacter pylori carbonic anhydrases. FEMS Immunol. Med. Microbiol., 44 (2005)183189.

15. I.R. Booth, Regulation of cytoplasmic $\mathrm{pH}$ in bacteria, Microbiol. Rev., 49 (1985) 359.

16. C. Ferradini, J.P. Jay-Gerin, The effect of $\mathrm{pH}$ on water radiolysis: a still open question-a minireview, Res. Chem., 26 (2000) 549-565.

17. W.D. Swiatla, Computation of the effect of $\mathrm{pH}$ on spur chemistry in water radiolysis at elevated temperatures, Nukleonika, 53 (2008) 31-37. 
18. A.J. Esbaugh, B.L. Tufts, The structure and function of carbonic anhydrase isozymes in the respiratory system of vertebrates, Respir. Physiol. Neurobiol., 154(2006) 185-198.

19. Aspatwar, A., Haapanen, S., and Parkkila, S., An Update on the Metabolic Roles of Carbonic Anhydrases in the Model Alga Chlamydomonas reinhardtii, Metabolites, 13 (2018).

20. C. Ward, J. Meehan, M. Gray, I.H. Kunkler, S.P. Langdon, D.J. Argyle, Carbonic Anhydrase IX [CAIX], Cancer, and Radiation Responsiveness, Metabolites, 10 (2018).

21. L. Dubois, S. Peeters, N.G. Lieuwes, N. Geusens, A. Thiry, S. Wigfield, F. Carta, et al., Specific inhibition of carbonic anhydrase IX activity enhances the in vivo therapeutic effect of tumor irradiation, Radiother. Oncol., 99 (2011) 424-431.

22. R.B. Kapust, J. Tozser, T.D. Copeland, D.S. Waugh, The P1 specificity of tobacco etch virus protease, Biochem. Biophys. Res. Commun., 294 (2002) 949-955.

23. Supuran CT, Capasso C. An Overview of the Bacterial Carbonic Anhydrases. Metabolites, 7 (2017) 56.

24. Doyen J., Parks S.K., Marcie S., Pouyssegur J., Chiche J. Knock-down of hypoxia-induced carbonic anhydrases IX and XII radiosensitizes tumor cells by increasing intracellular acidosis, Front. Oncol., 2 (2013) 199.

25. Chiche J., Brahimi-Horn M.C., Pouyssegur J. Tumour hypoxia induces a metabolic shift causing acidosis: A common feature in cancer, J. Cell. Mol. Med., 4 (2010) 771-794.

26. E. Gasteiger, C. Hoogland, A. Gattiker, M.R. Wilkins, R.D. Appel, A. Bairoch, Protein Identification and Analysis Tools on the ExPASy Server. In The Proteomics Protocols Handbook; Humana Press: New York, NY, (2005) 571-607.

27. S. Panda, G. Chandra, Physicochemical characterization and functional analysis of some snake venom toxin proteins and related non-toxin proteins of other chordates, Bioinformation, 8 (2012) 891-896.

28. R. Mohan, S. Venugopal, Computational structural and functional analysis of hypothetical proteins of Staphylococcus aureus, Bioinformation, 8 (2012) 722-728.

29. K. Pramanik, P.K. Ghosh, S. Ray, A. Sarkar, S. Mitra, T.K. Maiti, An In Silico Structural, Functional and Phylogenetic Analysis with Three Dimensional Protein Modeling of Alkaline Phosphatase Enzyme of Pseudomonas aeruginosa, J. Genet. Eng. Biotechnol., 15 (2017) 527-537.

30. K. Debashree, M. Saurov, T. Bhaben, In-Silico comparative structural modeling of carbonic anhydrase of the marine diatom Thalassiosira pseudonana Dates, J. Res. Bioinform., 1 (2012) 9-15.

31. K. Pramanik, P.K. Ghosh, S. Ray, A. Sarkar, S. Mitra, T.K. Maiti. An in silico structural, functional and phylogenetic analysis with three dimensional protein modeling of alkaline phosphatase enzyme of Pseudomonas aeruginosa, J. Genet. Eng. Biotechnol., 15 (2017) 527-537.

32. K. Pramanik, T. Soren, S. Mitra, T.K. Maiti. In silico structural and functional analysis of mesorhizobium ACC deaminase, Comput. Biol. Chem., 68(2017) 12-21.

33. P. Jaya, V.K. Nathan, P. Ammini, Characterization of marine bacterial carbonic anhydrase and their $\mathrm{CO}_{2}$ sequestration abilities based on a soil microcosm, Prep. Biochem. Biotechnol., 49 (2019) 891-899.

34. A.B. Murray, M. Aggarwal, M. Pinard, D. Vullo, M. Patrauchan, C.T. Supuran, R McKenna, Structural Mapping of Anion Inhibitors to $\beta$-Carbonic Anhydrase psCA3 from Pseudomonas aeruginosa, ChemMedChem., 13 (2018) 20242029.
35. S.R. Lotlikar, S. Hnatusko, N.E. Dickenson, S.P. Choudhari, W.L. Picking, M.A. Patrauchan, Three functional $\beta$-carbonic anhydrases in Pseudomonas aeruginosa PAO1: role in survival in ambient air, Microbiology, (2013) 1748-1759.

36. A. Eminoğlu, D. Vullo, A. Âşık, D.N. Çolak, C.T. Supuran, S. Çanakçı, A.O. Beldüz, Cloning, expression and biochemical characterization of a $\beta$-carbonic anhydrase from the soil bacterium Enterobacter sp. B13, J. Enzyme Inhib. Med. Chem., 31 (2016) 1111-1118.

37. P. Jaya, V.K. Nathan, P. Ammini. Characterization of marine bacterial carbonic anhydrase and their $\mathrm{CO}_{2}$ sequestration abilities based on a soil microcosm, Prep. Biochem. Biotechnol., 49 (2019) 891-899.

38. F. Chen, W. Jin, H. Gao, Z. Guo, H. Lin, J. Li, K. Hu, X. Guan, et al., Cloning, Expression and Characterization of Two Beta Carbonic Anhydrases from a Newly Isolated $\mathrm{CO}_{2}$ Fixer, Serratia marcescens Wy064, Indian J. Microbiol., 59 (2019) 64-72.

39. C.T. Supuran, Bacterial carbonic anhydrases as drug targets: towards novel antibiotics?, Front. Pharmacol., 2 (2011) 1-6.

40. R.A. Ynalvez, Y. Xiao, A.S. Warda, K. Cunnusamy, J.V. Moroney. Identification and characterization of two closely related $\beta$-carbonic anhydrases from Chlamydomonas reinhardtii, Physiol. Plant., 133 (2008) 15-26.

41. Nishimori I., Minakuchi T., Kohsaki T., Onishi S., Takeuchi H., Vullo D., Scozzafava A., Supuran C.T. (2007). Carbonic anhydrase inhibitors. The $\beta$-carbonic anhydrase from Helicobacter pylori is a new target for sulfonamide and sulfamate inhibitors, Bioorg. Med. Chem. Lett., 17 (2007) 3585-3594

42. Joseph P., Turtaut F., Ouahrani-Bettache S., Montero J. L., Nishimori I., Minakuchi T., Vullo D., Scozzafava A., Köhler S., Winum J. Y., Supuran C. T. Cloning, characterization and inhibition studies of a $\beta$-carbonic anhydrase from Brucella suis, J. Med. Chem., 53 (2010) 2277-2285

43. Vullo D, Nishimori I, Minakuchi T, Scozzafava A, Supuran CT. Inhibition studies with anions and small molecules of two novel $\beta$-carbonic anhydrases from the bacterial pathogen Salmonella enterica serovar Typhimurium, Bioorg Med Chem Lett., 21 (2011) 3591-3595.

44. Covarrubias AS., Bergfors T., Jones T. A., Hogbom M. (2006). Structural mechanics of the $\mathrm{pH}$-dependent activity of the $\beta$-carbonic anhydrase from Mycobacterium tuberculosis, J. Biol. Chem., 281 (2006) 4993-4999

45. R. Ramanan, K. Kannan, N. Vinayagamoorthy, K. Ramkumar, S. Sivanesan, T. Chakrabarti, Purification and characterization of a novel plant-type carbonic anhydrase from Bacillus subtilis, Biotechnol. Bioproc. E., 14 (2009) 32-37.

46. S.R. Lotlikar, S. Hnatusko, N.E. Dickenson, S.P. Choudhari, W.L. Picking, M.A. Patrauchan, Three functional $\beta$-carbonic anhydrases in Pseudomonas aeruginosa PAO1: role in survival in ambient air, Microbiology., 159 (2013) 1748-1759.

47. F. Chen, W. Jin, H. Gao, Z. Guo, H. Lin, J. Li, K. Hu, X. Guan, V.C. Kalia, J.K. Lee, L. Zhang, Y. Li, Cloning, Expression and Characterization of Two $\beta$ Carbonic Anhydrases from a Newly Isolated CO2 Fixer, Serratia marcescens Wy064., Indian J. Microbiol., 59 (2019) 64-72. 